\title{
Green Inhibitor for Mild Steel in Acidic Solution by Using Crude Extract and Polar Extract of Theobroma cacao Peels
}

\author{
YULI YETRI ${ }^{\star}$ and SUKATIK \\ Padang State Polytechnic Kampus Limau Manis Padang, Indonesia. \\ ${ }^{*}$ Corresponding author E-mail: yuliyetriyetri@gmail.com \\ http://dx.doi.org/10.13005/ojc/330456
}

(Received: June 01, 2017; Accepted: June 29, 2017)

\begin{abstract}
Corrosion inhibition and adsorption properties of the crude extract and polar extract of Theobroma cacao peels on mild steel in $\mathrm{HCl} 1.5 \mathrm{M}$ was studied using the method of weight lost and potentiodynamic polarization (Tafel). Inhibition efficiency were measured for immersion for 192 hours, the concentration of the extract $0.5-2.5 \%$ with an interval of $0.5 \%$ and the rang of temperature (303-323) K. Electrochemical polarization evaluated to know the type of inhibitor. Infrared spectra and GCMS were conducted to determine the extract compounds that act in the inhibition process. The surface morphology of samples was observed by a photo optical. The results showed that the corrosion rate decreases with increasing the concentration of the extract and increases with increasing temperature. Inhibition efficiency for crude extract and polar extract was $83.45 \%$ and $96.26 \%$ (weight loss), $85.23 \%$ and $92.08 \%$ (Tafel) and $72.29 \%$ and $83.95 \%$ (303 K) at $2.5 \%$ of concentration of extract. The increase in the efficiency of inhibition was also followed by an increase in the degree of surface coverage of a chemical adsorption is happening on the surface. Adsorption that occurred on the surface of mild steel obeys the Langmuir isotherm. This polarization curve indicates inhibitor behaves as mixture inhibitor with predominantly on cathodic inhibition. Apparently, the polar extract is more effective to reduce the corrosion rate than crude extract. The addition of polar extract of cacao into a solution of $\mathrm{HCl}$ is very effective to reduce the attack corrosion of the mild steel surface.
\end{abstract}

Keywords: Cacao peels extract, Corrosion inhibitor, Tafel, Adsorption, GCMS

\section{INTRODUCTION}

Mild steel has a high popularity, since these metals have the ability to be used in a wide variety of needs, weld able, and relatively cheap. Because of this ability, the mild steel is widely used as a commercial commodity to make constructions, automotive, industrial machinery, industrial vehicles, and more. Besides advantages, these metals also have weaknesses, namely: easily corroded. Corrosion is a spontaneous process that occurs in metals that want to return to forms previously, therefore necessary maintenance to reduce the corrosion rate. There are several ways to slow 
the rate of corrosion, namely: coatings, cathodic or anodic protection, and electro deposition and with the addition of inhibitor ${ }^{1}$. The use of corrosion inhibitor prevention is one of the most efficient and economical, because these compounds will protect the surface of mild steel, from the corrosive medium by forming a passive layer (protective layer) on its surface ${ }^{2}$.

Corrosion inhibitors are compounds that when added in small amounts can reduce the rate of corrosion in aggressive media efficiently. Commonly used corrosion inhibitor compound is a compound containing atoms of $\mathrm{N}, \mathrm{P}, \mathrm{O}, \mathrm{S}$, or $\mathrm{As}^{3}$. Have many natural ingredients extracts were trying to get environmentally friendly corrosion inhibitors, and non-toxic mainly taken from the flower extrac ${ }^{14}$, fruit skins $^{1,5}$, leaves ${ }^{6}$, and seeds ${ }^{7}$. Such as henna leaves ${ }^{8,}$ green tea ${ }^{9}$, vegetable ${ }^{10}$, Gracinia mangosteen peels ${ }^{11}$, papaya leaves ${ }^{12}$, Solanum melongena leaves ${ }^{13}$, and pineapple leaves ${ }^{14}$.

In the other side, Indonesia as the country's No. 3 producer of cacao beans in the world has the potential as a source of corrosion inhibitor. Because $(70-75) \%$ of the cacao fruit product is waste peels. The peels waste has the potential to be used as a corrosion inhibitor, because until now the waste is not used optimally. Cacao peels have tannin compounds $\left(\mathrm{C}_{76} \mathrm{H}_{52} \mathrm{O}_{46}\right)$ is quite large, with a monomer such as, digallic acid and D-glucose ${ }^{15}$. These monomers rich with free electron pairs which can form covalent bond coordination on the metal surface, so as to slow the rate of corrosion ${ }^{1}$.

\section{Research Methodology \\ Preparation Materials}

Before using, the chemical composition of mild steel checked by Foundry-Master Xpert Spectrometre. The chemical composition obtained from the test are: Fe (97.8), Mn (0.9), P (0.07), C $(0,32)$, Si (0.22), S (0.06) , Cr (0.1), Cu (0.3), Mo (0.02), $\mathrm{Al}(0.006)$, Co (0.0053), $\mathrm{Ni}(0.08) \%$ by weight. The results showed that the mild steel including low carbon steel. Mild steel surface preparation and manufacture of cacao peels extract until ready to use for testing already explained in previous journal ${ }^{1}$.

\section{Gas Chromatography Mass Spectrometry}

To identify what compound that plays a role in the inhibition of corrosion of mild steel, the composition of the cacao peels extracts analyzed using gas chromatography mass spectrometry
(GCMS) by SHIMADZU GCMS-QP2010S, with parameter initial temperature $70{ }^{\circ} \mathrm{C}$ and a maximum of $324{ }^{\circ} \mathrm{C}$ for 50 minutes. To find compounds that play a role in slowing the rate of corrosion, analysis of functional groups with FTIR Nicolet brand is 10-FTIR spectrophotometer (Thermo Scientific Company, USA), with wavelengths ranging 4,000 to $400 \mathrm{~cm}^{-1}$.

\section{Corrosion Rate and Inhibition Efficiency}

Mild steel which has been prepared each weighed to determine the initial mass. Then soaked in corrosive media $\mathrm{HCl} 1.5 \mathrm{M}$ for 192 hours, with the inhibitor concentration variation were $0.5 \%$, $1.0 \%, 1.5 \%, 2.0 \%$ and $2.5 \%$. As for the effect of temperature is done at (303-323) $\mathrm{K}$ and heated for 6 hours with $2.5 \%$ inhibitor concentration. After the corrosion process running for a predetermined time, corrosion products removed from the media corrosion, washed carefully by using a soft brush, then rinsed with distilled water and finally rinsed with acetone. Subsequently dried at room temperature, and weighed as the final mass. The rate of corrosion and inhibition efficiency calculated by equations 1 and 2 below:

$$
\begin{aligned}
& C R=\frac{(m 0-\mathrm{m} 1)}{A . t} \\
& E I=\frac{(C R 0-\mathrm{CR} 1)}{C R 0} \times 100 \% \\
& \theta=\frac{(C R 0-\mathrm{CR} 1)}{C R 0}
\end{aligned}
$$

Where: $m_{0}=$ initial mass, $m_{1}$ final mass, $\mathrm{CR}_{\mathrm{O}}=$ rate of corrosion reaction without inhibitor and $\mathrm{CR}_{1}=$ rate of corrosion reaction with inhibitor. $\mathrm{A}$ $=$ area of the specimen in $\mathrm{cm}^{2}, \mathrm{t}=$ exposure time in hours, $\Theta=$ degrees of surface coverage

\section{Potentiodynamic Polarization}

First, do the preparation of computer controlled potentiostat instrument EDAQ Potentiostat 466-Advanced Electrochemical System and solution to be used. Then, mild steel that will be used is placed on the holder of footage, and then dipped into a corrosion cell that contains a solution of 10 $\mathrm{mL}$ of media corrosion. Inside the cell corrosion, mild steel will serve as the working electrode. After that, put auxiliary electrode and the reference electrode (EKJ) into the cell corrosion, then a third electrode is connected to the potentiostat instrument. And do measurements with a scan speed of $0.1 \mathrm{mV} / \mathrm{sec}$. 
Measurements will be obtained from the corrosion current density (Icorr), corrosion potential (Ecorr) and polarization resistance (Rp). With the help of software tools acquired Tafel curve, while the rate of corrosion and inhibition efficiency using the formula 4 below:

$I E \%=\frac{I \operatorname{corr}-\operatorname{Icorr}(\mathrm{inh})}{C R 0} \times 100 \%$

Where, Icorr and Icorr (inh) is the current density and corrosion without and with of inhibitors.

\section{Surface Morphology}

After testing the corrosion rate, the sample surface is analyzed using a microscope Photo Trinoculer Carton Stereo Optical, which aim is to see the form of corrosion on the surface of the sample before and after the corrosion.

\section{RESULTS AND DISCUSSION}

\section{Analysis GCMS (Gas Chromatography Mass Spectrometry)}

Analysis of the crude extract and polar extract produce many spectra as shown in
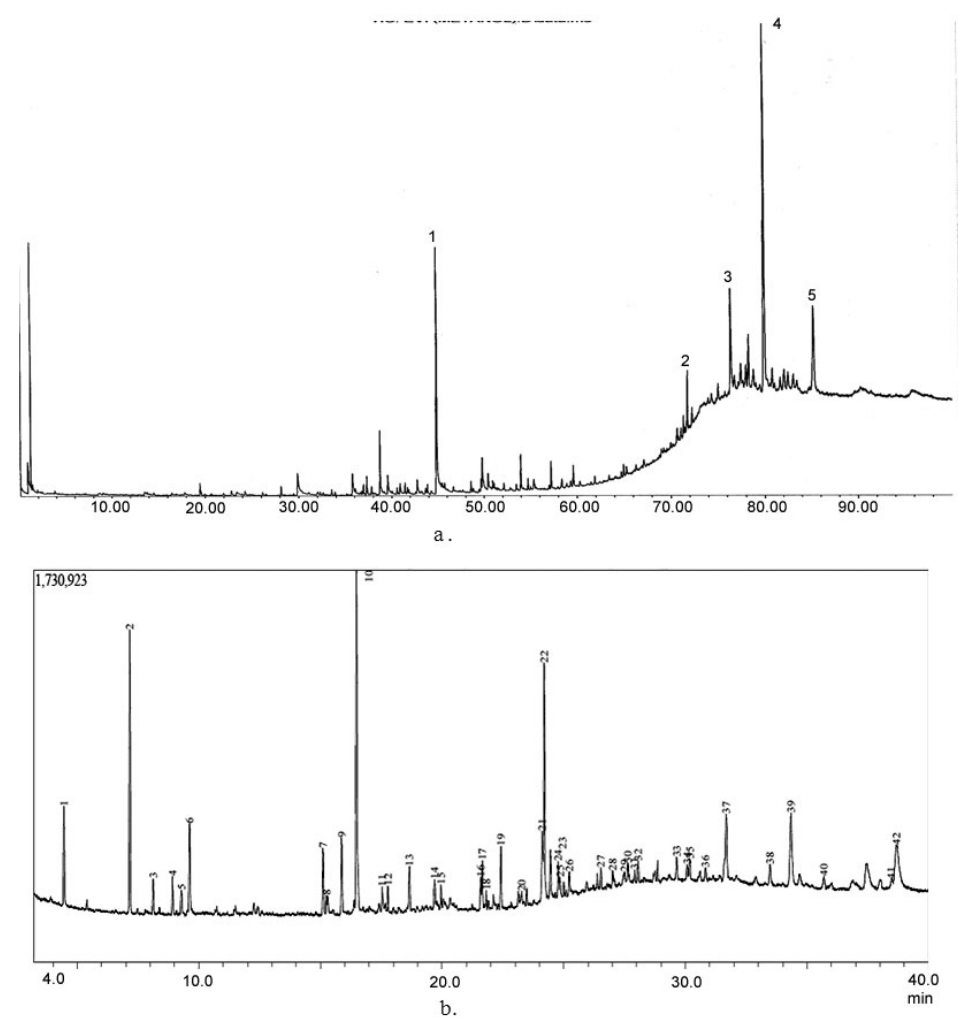

Fig. 1: GCMS spectra of cacao peels. a) crude extract, and b) polar extract

Table 1: The compound contained in the crude extract and polar extract of cacao peels

\begin{tabular}{lllll}
\hline No. & Crude extract & Formula & Polar extract & Formula \\
\hline 1 & n-hexadecanoid acid & $\mathrm{C}_{16} \mathrm{H}_{22} \mathrm{O}_{2}$ & Benzenedic carboxyclic acid & $\mathrm{C}_{24} \mathrm{H}_{38} \mathrm{O}_{4}$ \\
2 & Ergosta 5, 22 dien-3-ol, acetate & $\mathrm{C}_{30} \mathrm{H}_{48} \mathrm{O}_{2}$ & Benzeenamine & $\mathrm{C}_{7} \mathrm{H}_{9} \mathrm{~N}$ \\
3 & B-Sitosterol & $\mathrm{C}_{29} \mathrm{H}_{50} \mathrm{O}$ & Phenol-2 methoxy-4(2-propenyl) & $\mathrm{C}_{12} \mathrm{H}_{14} \mathrm{O}_{3}$ \\
4 & Stigmas & $\mathrm{C}_{29} \mathrm{H}_{48} \mathrm{O}$ & Phenol-2 methoxy-5(1-propenyl) & $\mathrm{C}_{10} \mathrm{H}_{12} \mathrm{O}_{3}$ \\
5 & Stimastane-3-6 dione & $\mathrm{C}_{29} \mathrm{H}_{48} \mathrm{O}_{2}$ & $\begin{array}{l}\text { Benzoic acid (alpha 3,4 tris } \\
\text { trimethylsilydoxy) }\end{array}$ & $\mathrm{C}_{16} \mathrm{H}_{33} \mathrm{O}_{4} \mathrm{Si}_{3}$ \\
& & & \\
\hline
\end{tabular}


Figure 1. For the purposes of analysis is then selected five compounds in the extracts which have a dominant peak area, as summarized in Table 1.

\section{Analysis of corrosion rate by Weight loss methods}

Testing of corrosion rate with the method of weight loss seen indications of adding the inhibitor would minimize weight loss, and reduction the rate of corrosion after giving inhibitor as shown in Figures 2 and 3 . In contrast, the increasing the concentration of the inhibitor would increase the efficiency of inhibition on the surface of mild steel, the relationship in Figure 4 can be seen. This is because the larger the surface of the metal in contact with the solution the more mild steel surface coated by extract of cacao peels. The process in accordance with protection mechanisms that have been described, that extract natural materials are compounds containing an atom that has a lone pair of electrons ${ }^{3}$. These atoms act as electron donors so that it will form a complex compound with iron. These complex compounds are stable, not easily oxidized and will envelop ferrous metal surface, so that the rate of corrosion can be inhibited.

Analysis of the results of Figure 2 shows that, the weight reduction at polar extract smaller than crude extract and corrosion rate of extract polar is also smaller than the crude extract. So that efficiency of polar extract is higher than crude extract at the same concentration, as shown in Figures 2 and 3 . This is because the polar extract is widely available poliphenol compound with high molecular weight and has a lot of heteroatom group which can form a thin film on the surface of the mild steel. The layer serves as a barrier that can slow the rate of corrosion ${ }^{16}$. So that, the smaller the corrosion rate, the higher the efficiency of inhibition ${ }^{17}$.

Increasing the efficiency of inhibition of polar extract of cacao peels because, many heteroatom compounds and hydroxyl group can be adsorbed on

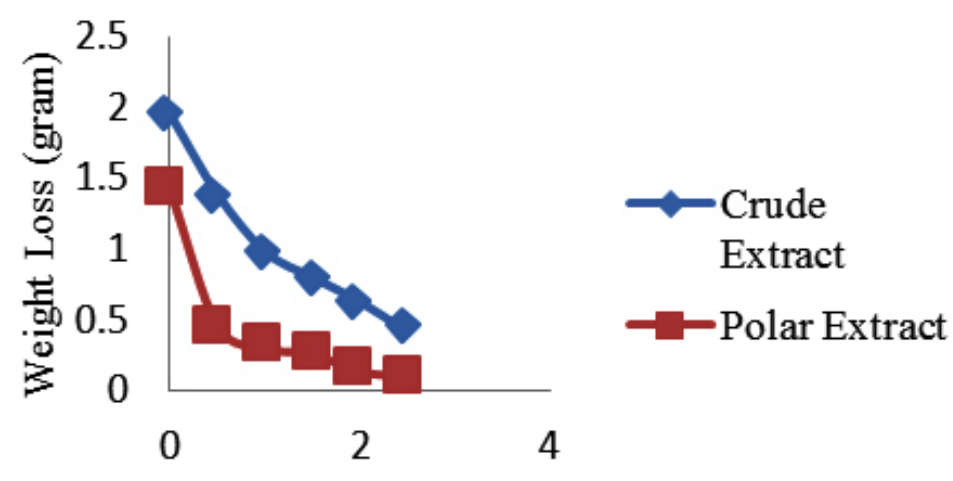

Concentration of Extract (\%)

Fig. 2: Weight Loss vs. Concentration of Extract

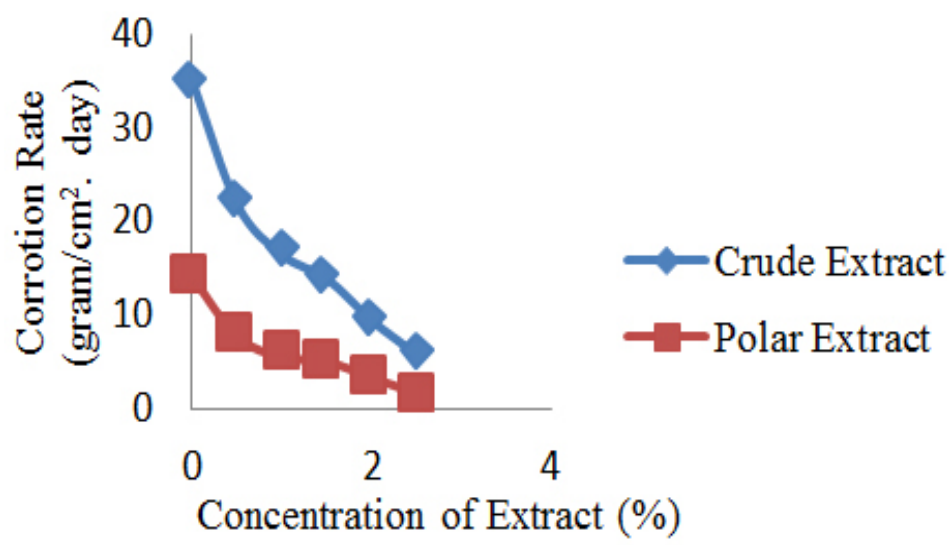

Fig. 3: Corrosion rate vs. Concentration of extract 


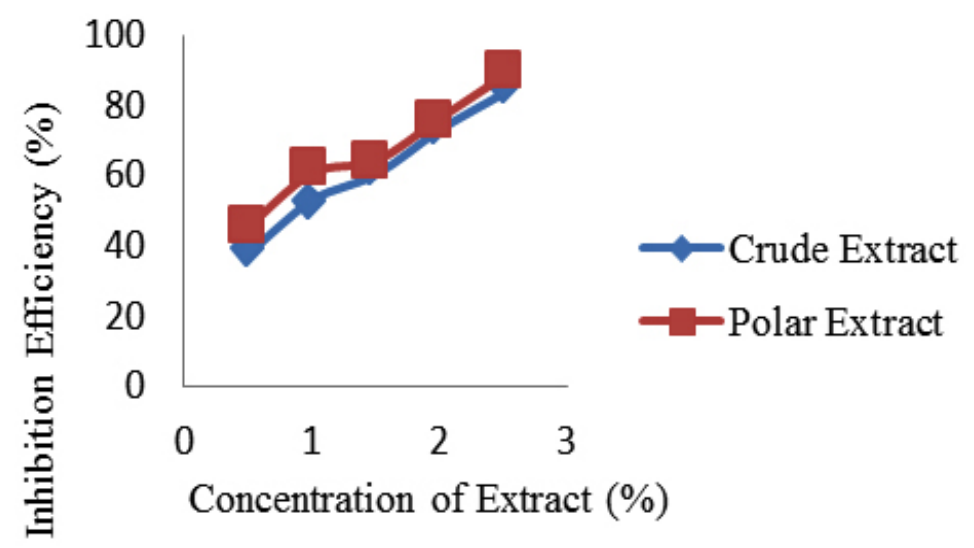

Fig. 4: Inhibition Efficiency vs. Concentration of Extract

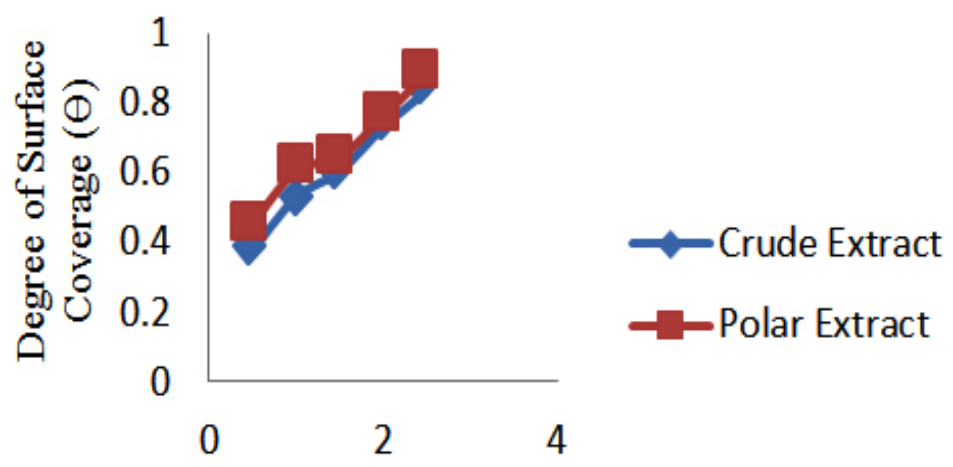

Consentrasion of Extract (\%)

Fig. 5: Degree of Surface Coverage vs. Concentration of Extract Potentiodynamic polarization analysis

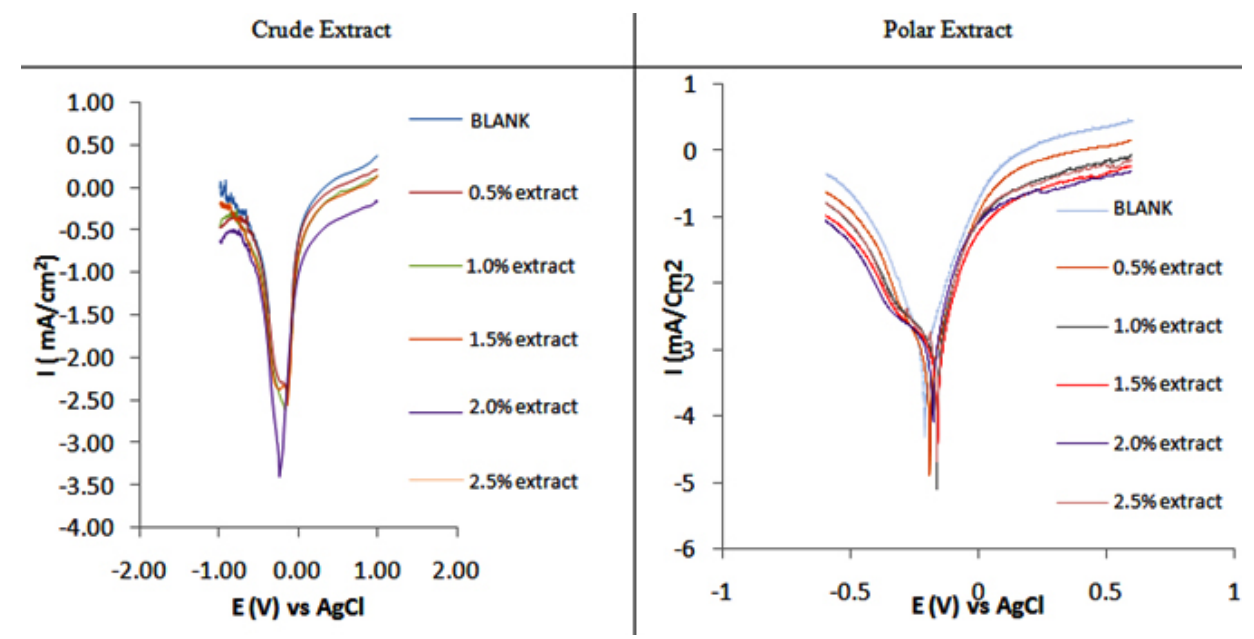

Fig. 6: Polarization curves of the mild steel without and with Theobroma cacao peels extract in $\mathrm{HCl} 1.5 \mathrm{M}$ 
the surface of mild steel compared with the crude extract. Adsorption extract in mild steel surface to form a stable complex that can protect mild steel from attack ions contained in corrosive media ${ }^{2,18}$.

The value of the corrosion rate of mild steel without and with the addition of cacao peels extract is used to determine the degree of surface coverage of mild steel using equation 3. Figure 5 show that the higher concentration of inhibitor, the value of the degree of surface coverage of mild steel higher to. It shows almost the entire surface of the mild steel covered by cacao peels extract, so the attack of aggressive ions of $\mathrm{H}^{+}$and $\mathrm{Cl}^{-}$from the acid medium hindered because the extract layer on the surface of mild steel ${ }^{2,19}$.

Potentiodynamic polarization analysis in $\mathrm{HCl}$ $1.5 \mathrm{M}$ medium without and with the addition of the cacao peels extract using eDAQ potentiostat. From the analysis of potentiodynamic polarization curves obtained with the current relationship between the potential. Potentiodynamic polarization curves show the interaction interface between the solutions with the electrode. These interactions lead to polarization and a certain flow. Polarization curve extrapolated to the Tafel method to determine the value of the corrosion current (Icorr), corrosion potential (Ecorr) and inhibition efficiency (\% $\mathrm{El})$ is determined by the equation 4. The Tafel plot analysis of data obtained are summarized in Figure 6 and Table 2.

From Table 2 shows that the corrosion current density generated from both the extract is getting smaller with increasing concentration of extract added. By decreasing the current density generated will reduce the mass loss of mild steel as shown in Figure 2. This is because peels extract of cacao form a thin layer on the surface of mild steel, so that the corrosion rate can be slowed, and the inhibition efficiency could be improved ${ }^{20}$. Data were elaborated at Table 2 also confirmed by the test data by the method of weight loss in Figures 3 and 4.

If we compare the test results from the two extracts in Table 2, it appears that the polar extract a much higher rate of corrosion attack on the ability to protect the surface of mild steel compared to the crude extract. This is evident from the current density generated polar extract, half lower than the current density generated by the crude extract of the cacao peels extract to the same concentration. As a result, the ability of inhibition efficiency polar extract is also greater than the crude extract, which extract is added to a concentration of $2.5 \%$ was obtained inhibition efficiency of $92.08 \%$ for the polar extract and $85.23 \%$ for the crude extract.

Table 2: Electrochemical and corrosion parameter mild steel, with and without the addition of cacao peels extract in $\mathrm{HCl} 1.5 \mathrm{M}$ after immersed 6 days (192 hours)

\begin{tabular}{llllllll}
\hline No. & $\begin{array}{l}\text { Concentration } \\
\text { Inh (\%) }\end{array}$ & \multicolumn{3}{c}{ Crude extract } & \multicolumn{3}{c}{ Polar extract } \\
\cline { 3 - 8 } & & $\mathrm{E}_{\text {corr }}$ & $\mathrm{I}_{\text {corr }}$ & $\mathrm{El}(\%)$ & $\mathrm{E}_{\text {corr }}$ & $\mathrm{I}_{\text {corr }}$ & El(\%) \\
\hline 1. & 0.0 & -0.4100 & 0.0694 & - & -0.2800 & 0.0631 & - \\
2. & 0.5 & -0.4000 & 0.0495 & 28.6700 & -0.2750 & 0.0159 & 74.8100 \\
3. & 1.0 & -0.3940 & 0.0273 & 60.6600 & -0.2500 & 0.0126 & 80.8300 \\
4. & 1.5 & -0.3900 & 0.0203 & 70.7500 & -0.2000 & 0.0079 & 87.8400 \\
5. & 2.0 & -0.3880 & 0.0132 & 80.7800 & -0.2200 & 0.0066 & 89.5400 \\
6. & 2.5 & -0.3800 & 0.0100 & 8502300 & -0.2800 & 0.050 & 92.2800 \\
\hline
\end{tabular}

Table 3: The thermodynamic variables with and without extracts $2.5 \%$

\begin{tabular}{cllll}
\hline No. & Variabel & HCl 1.5M & HCl 1.5M + Crude extract & HCl 1.5M + polar extract \\
\hline 1. & $\mathrm{Ea}$ & 101.0619 & 117,1014 & 198.8048 \\
2. & $\Delta \mathrm{H}$ & 98.42 & 114.46 & 196.1423 \\
\hline
\end{tabular}


Analysis of weight loss with the variation of temperature is used to determine the stability of the adsorbate layer of cacao peels extract on the surface of mild steel in the process of corrosion in hydrochloric acid medium. Measurement of the value of the mass loss of mild steel with temperature variation is determined by immersion of mild steel in $\mathrm{HCl}$ medium without and with the addition of extract at temperature variation (303-323) $\mathrm{K}$ for 6 hours of immersion time. The data obtained in Figure 7 shows that, the corrosion rate of mild steel increases with increasing temperature. The increase in temperature resulted $\mathrm{Fe}$ oxidation reaction on the surface of mild steel and chemical reactions of the corrosive medium also increased. The result is the removal of the adsorbate of cacao peels extract on the surface of mild steel, so the corrosion rate increases with increasing temperature ${ }^{21,22}$. The value of the corrosion rate of mild steel in $1.5 \mathrm{M} \mathrm{HCl}$ corrosive medium without and with the addition of cacao peels extract on these temperature variations are used to determine the activation energy value as shown in Table 3.

\section{Adsorption Isotherms}

Based on the interaction between the cacao peels extract with mild steel surface of the obtained adsorption isotherm ${ }^{2}$. The value of the degree of surface coverage $(\varnothing)$ with the addition of cacao peels extract in medium hydrochloric acid contained in Figure 6 is used to describe the adsorption isotherm. The adsorption of organic molecules at the interface of a metal with a solution based on the adsorption process of substitution between the organic molecules in solution with water molecules on the surface of mild steel ${ }^{2,23}$.

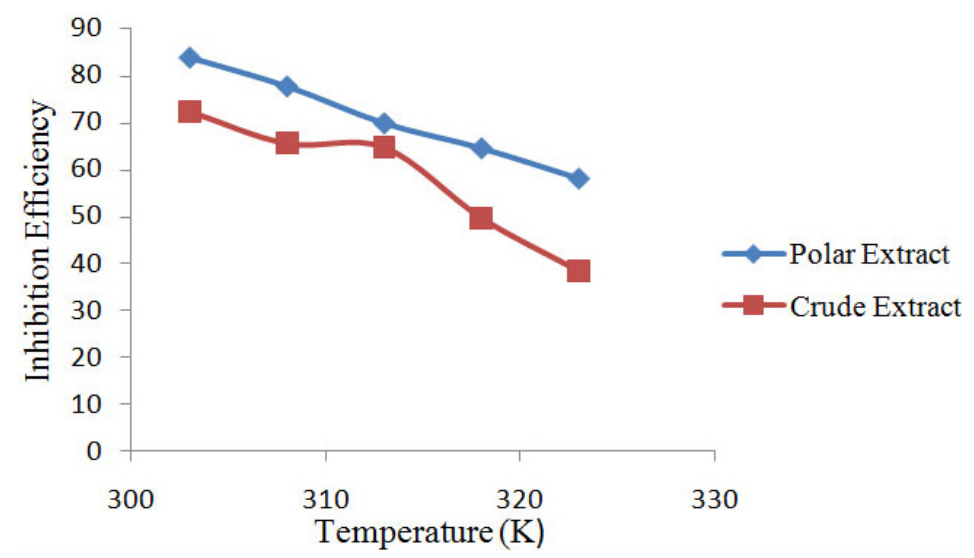

Fig. 7: Effect of temperature on the rate of corrosion of mild steel in $\mathrm{HCl} 1.5 \mathrm{M}$ after heated 6 hours without and with the addition of the cacao peels extract $2.5 \%$

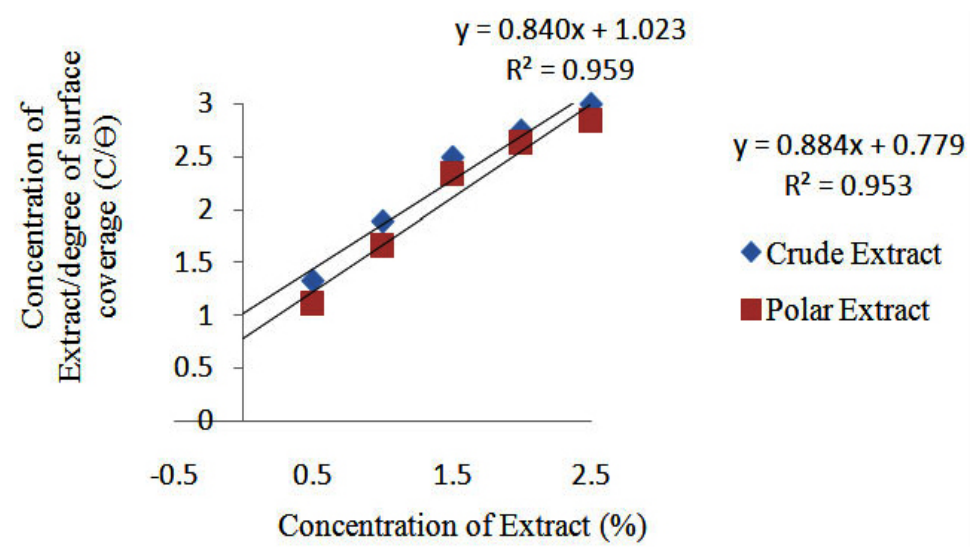

Fig. 8: Flow Langmuir adsorption isotherms for the adsorption of cacao peels extracts in $\mathrm{HCl} 1.5 \mathrm{M}$ medium at temperature of $298 \mathrm{~K}$ 


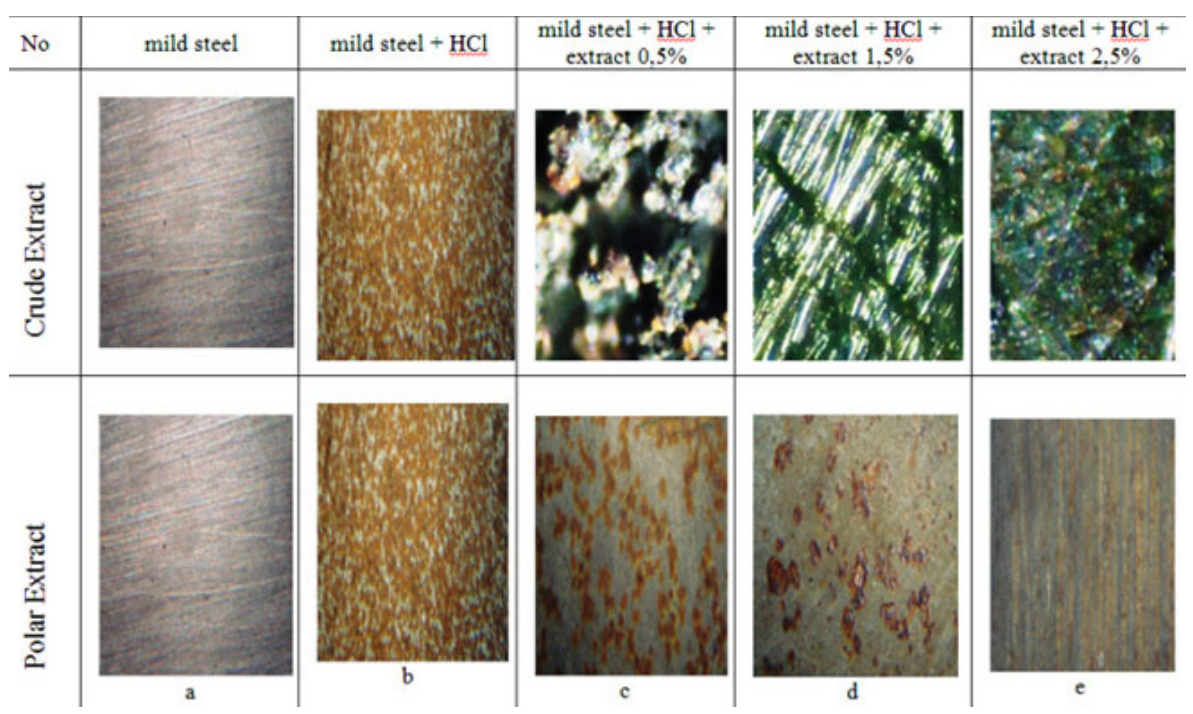

Fig. 9: The surface morphology of mild steel with an optical microscope without and with extract of cacao peels in various concentrations in $\mathrm{HCl} 1.5 \mathrm{M}$. a). mild steel polished, b). dipped in $\mathrm{HCl}$, while $\mathrm{c}, \mathrm{d}$, and e with the addition of extracts of $0.5 \%, 1.5 \%$ and $2.5 \%$

The results of the comparison chart analysis inhibitor concentration with the degree of surface coverage vs. inhibitor concentration variations of adsorption isotherms obtained graph is a straight line like Figure 8. Its figure shows that the adsorption isotherms on the surface in mild steel with the addition of the cacao peels extract followed Langmuir adsorption isotherm. Langmuir adsorption isotherm assumes that the cacao peels extract adsorption on the surface of mild steel form a monolayer ${ }^{24}$.

\section{The Surface of Morphology}

The observation of the surface morphology and mild steel without and with of cacao peels extracts by photo optics before and after treated with 100x magnification can be seen in Figure 9a-9g.

Photo initial surface morphology of the specimen can be seen in Figure 9a, the pictures look their fine lines white is very smooth and relatively thin which is the effect of grinding and sanding the surface of mild steel. Also seen that the surface is flat, clean, there are no holes, and non-porous. It is not as yet a corrosion reaction because there is no influence from the environment such as water, air, acids, salts, bases or from corrosive substances. While in Figure 9b shows the morphology of the surface of mild steel after immersed for eight days in a corrosive solution of $\mathrm{HCl} 1.5 \mathrm{M}$. From these images clearly visible hydrochloric acid attacks against mild steel corrosion even produced tend to be damaging its surface. In Figure 9c-9e shows the effect of the use of inhibitors of cacao peels extract to slow the rate of corrosion ${ }^{1}$. Cacao peels extract as inhibitors able to withstand the corrosive attack from the acid chloride. The result showed that the greater the concentration of cacao peels extract inhibitor is used, the damage is also diminishing. Because corrosion product formed decreases with increasing concentration of inhibitor used. This shows that the inhibitor is able to form a layer that can block the attack of aggressive ions such as acid so that the surface of mild steel be protected and protected by a thin layer on the surface, so that the corrosion rate is slower ${ }^{24,25,26,}$.

\section{CONCLUSION}

The crude extract and polar extract of cacao peels act as good and efficient inhibitors for corrosion of mild steel in $1.5 \mathrm{M}$ hydrochloric acid medium. Potentiodynamic polarization studies revealed that both of the extract act through mixed mode of inhibition with dominant cathodic inhibitor. The mechanism involved in this study is the phytochemical constituents in the plant extracts that have adsorbed on the mild steel surface forming a protective thin film layer ${ }^{26}$. Its film preventing the discharge of $\mathrm{H}^{+}$ions and dissolution of metal ions and 
has prevented the small corrosion on the surface of the metal ${ }^{27}$. The cacao peels extracts obey Langmuir adsorption isotherm ${ }^{26,27}$. The photo optic morphology of the adsorbed protective film on the mild steel surface has confirmed the high performance of inhibitive effect of the extract of cacao peels. Results obtained in weight loss method were very much in good agreement with the electrochemical methods (potentiodynamic polarization method) in the order polar extract is stronger inhibiting than crude extract. Among the two extracts studied from cacao peels, the maximum inhibition efficiency was found in polar extract which showed $96.26 \%$ inhibition efficiency at $2.5 \%$ concentration of the extract.

\section{ACKNOWLEDGMENT}

The first author would like to thank the Indonesian government for BPPS scholarships and Hibah Disertasi Doctor no. DIPA 042. 05.28.33421/2014.

\section{REFERENCES}

1. Yetri Y.; Emriadi, Novesar J.; Gunawarman. Asian Journal of Chemistry. 2015, 27(3), 875881.

2. M. Shyamala; P.K. Kasthuri. International Jurnal of Corrosion, 2012, 1-13.

3. S. Nofrizal; Afidah A. Rahim; Bahruddin Saad; P. Bothi Raja; Affaizza M. Shah; S. Yahya. Metallurgical and Materials Transactions A, 2012, 43(4), 1382-1393.

4. Hasan S. K..; Edrah S. J. Ind. Res Tech. 2012, 1(2), 110-113.

5. Gunavathy N.; Murugavel S.C. E-Journal of Chemistry. 2012, 9(1), 487-495.

6. C. A. Loto. Corrosion Prevention and Control. 2001, 48(1), 38-41.

7. R. Rajalakshmi; S. Subhashini; M. Nanthini; M. Srimathi. Oriental Journal of Chemistry. 2009, 25(2), 313-318.

8. Al-Sehaibani H. Mat.-wiss.u. Werkstofftech, 2000, 31, 1060-1063.

9. A.M. Alsabagh; M. A. Migahed; M. Abdelraouf; E.A. Khamis. Int. J. Electrochem. Sci. 2015, 10, $1855-1872$

10. Ghadah M. Al-Senani; Sameerah I. AISaeedi; Rasmiah Almufari. Oriental Journal of Chemistry. 2015, 31(4), 2077-2086.

11. K.P. Vinod Kumar; M.S. Narayanan Pillai; G. Rexin Thusnavis. Portugaliae Electrochimica Act. 2010, 28, 373-383.

12. Loto C. A; Loto R.T; Popoola A.P.I. Int. J. Electrochem. Sci. 2011, 6, 4900-4914.

13. Ugi, B. U; Fountain Journal of Natural and Applied Sciences. 2014, 3(1), 1 -9.

14. Ekanem.U.F; Umoren, S.A.; Udousoro, S.A.; Udoh, A.P. J.Mater. Scie. 2010, 45, 55585566.

15. T. Okuda; H.Ito. J. Molecule. 2011, 16, 2191-
2217.

16. J. C. da Rocha; J. A. da Cunha Ponciano Gomes; E. D'Elia. Corrosion Science. 2010, 52(7), 2341-2348.

17. Yuli Yetri; Emriadi; Novesar J; Gunawarman. Journal of Chemical And Pharmaceutical Research. 2015b, 7(15), 1083-1094

18. L. Afia; Rachid Salghi; El Houcine Bazzi. Res Chem Intermed. 2012, 38, 1707-1717.

19. Gerengi H; Halil Ibrahim Sahin. Industrial Engineering Chemical Research. 2011, 51, 780-787.

20. Oguzie E E; Okolue B N; Ebenso E E; Onuoha G N; Onuchukwu A I. Mater Chem Phy. 2004, 87(2-3), 394-401.

21. M. H. Hussin; M. J. Kassim. Int. J. Electrochem. Sci. 2011, 6, 1396-1414.

22. Li. X; Deng. S; Fu. H; Li. T. Electrochim Acta. 2009, 54, 4089-4098.

23. Kumaravel Mallaiya; Rameshkumar Subramaniam; Subramanian Sathyamangalam Srikandan; S. Gowri; N. Rajasekaran; A. Selvaraj. Electrochimica Acta. 2011, 56(11), 3857-3863

24. Loto C.A. J. Mater. Environ. Sci. 2012, 1(3), 195-205.

25. Assyar Nahle; Yassir El Quadi; Abdel Hamid Bouyanzer; Louw Majidi; Lhou Majidi; Yulien Paolini; Jean Costa; Marie Desjobert; Nabila Chauboun; Abdel Kadel Zarrouk; Belkheir Hammouty. Orient.J..Chem.2016, 32( 4), 1909-1921.

26. Kanbarasi. Oriental Journal of Chemistry. 2016, 32(4), 2139-2145.

27. Roland Tolulope Loto; Eboh Oghenerukewe. Orient.J..Chem.2016, 32(5), 2813-2832. 